\title{
Modification of Periodate Oxidation Method to Produce HRP-IgG Conjugate and Test its Stability Overtime
}

\author{
Nataliia Pavliuchenko', Victoria Hazarnian², Marcel Bassil1,2* \\ ${ }^{1}$ Biotechnology Department, Benta Pharma Industries, Dbayeh, Lebanon \\ ${ }^{2}$ Faculty of Pharmacy, Lebanese University, Rafic Hariri University Campus, Hadath, Lebanon \\ Email: *marcel.bassil@benta.com.lb
}

How to cite this paper: Pavliuchenko, N., Hazarnian, V. and Bassil, M. (2019) Modification of Periodate Oxidation Method to Produce HRP-IgG Conjugate and Test its Stability Overtime. American Journal of Molecular Biology, 9, 52-63.

https://doi.org/10.4236/ajmb.2019.92005

Received: February 18, 2019

Accepted: April 13, 2019

Published: April 16, 2019

Copyright () 2019 by author(s) and Scientific Research Publishing Inc. This work is licensed under the Creative Commons Attribution International License (CC BY 4.0).

http://creativecommons.org/licenses/by/4.0/

\begin{abstract}
Goat anti-Rabbit Horseradish Peroxidase (HRP) secondary conjugate was produced using a modified periodate oxidation method. The obtained conjugate was tested in the quality control techniques of therapeutic proteins. To determine the working dilution, titration of the prepared conjugate was performed in Indirect Enzyme-Linked Immunosorbent Assay (ELISA) and found to be 1:5000. This dilution was further tested in Western Blot analysis. The secondary conjugate was kept at $4^{\circ} \mathrm{C}$ for one month and its stability was verified by Western Blot and Indirect ELISA techniques.
\end{abstract}

\section{Keywords}

Antibody, Conjugation, Horseradish Peroxidase (HRP), Indirect ELISA, Periodate-Mediated Glycoprotein Oxidation

\section{Introduction}

Primary and secondary antibodies are used for detection and quantification of antigens in immunoassays such as ELISA, Western Blotting and immunohistochemistry [1]. Antibodies can be labeled with a variety of molecules such as biotin, fluorescent tags, radioactive molecules, and enzymes such as Horseradish Peroxidase, alkaline phosphatase, glucose oxidase, and $\beta$-galactosidase [2] [3] [4]. Horseradish Peroxidase is the most common enzyme used for conjugation because it is a small molecule, not expensive, stable and highly detectable chromogenic, chemiluminescent and fluorogenic substrates are available [5].

Many HRP-IgG conjugation methods are available, such as glutaraldehyde, cyanuric chloride, p-benzoquinone, maleimide methods, periodate oxidation, 
etc. Some of the advantages of using periodate oxidation method are as follows: it is a simple and cheap method that results in many aldehyde groups available for coupling, and also no side reactions are present, and antibodies can be used without previous modification [6] [7].

Conjugation of enzymes to antibodies involves the formation of a stable, covalent linkage between the two molecules; such coupling is achieved using a cross-linking agent, which reacts with the functional groups present in both enzymes and antibodies. Functional groups in proteins include amino, imino, hydroxyl, thiol and phenol groups [8].

Periodate mediated conjugation of HRP to the antibody (first described by Nakane and Kawaoi, 1974) is one of the most popular, simple methods to prepare conjugates that can be used in enzyme immunoassays. This method is based on Sodium periodate oxidation of carbohydrate side chains of HRP, followed by activation of Schiff base between activated peroxidase and amino groups of the antibody. The stable conjugate formed is after the reduction of the Schiff base by Sodium Borohydride [9].

Enzyme-labeled antibodies can be used in the pharmaceutical industry for the quality control of therapeutic proteins, such as Erythropoietin.

In this study, Goat anti-Rabbit antibodies were labeled with Horseradish peroxidase using periodate oxidation method. Micro-concentration of HRP-Sodium Periodate solution was done to remove the excess of periodate in order to simplify and accelerate the first step of conjugation. The reduction of the Schiff base of HRP-IgG conjugate by Sodium Borohydride was tested by incubating the solution for 90 minutes and overnight before final dialysis of labeled $\mathrm{Ab}$. The Western Blot and ELISA results showed no significant difference between conjugates stabilized for 90 minutes and overnight.

In addition, the results obtained from Indirect ELISA and Western Blot techniques of Erythropoietin, using conjugated secondary antibodies showed that prepared conjugates were effective and stable for 1 month at $+4^{\circ} \mathrm{C}$.

\section{Materials and Methods}

\subsection{Purification of IgG}

Antibodies from lyophilized Goat Anti-Rabbit serum were manually purified by affinity chromatography using Pierce ${ }^{\mathrm{m}}$ Chromatography Cartridges Protein $\mathrm{G}$ (Thermo Scientific). IgGs were eluted by Glycine buffer ( $\mathrm{pH}$ 2.5) followed by $\mathrm{pH}$ adjustment with Tris- $\mathrm{HCl}(1 \mathrm{M}, \mathrm{pH} 8.5)$, and obtained fractions were stored at $-20^{\circ} \mathrm{C}$ [10]. Two fractions $(20 \mathrm{mg} / \mathrm{ml}$ and $8.23 \mathrm{mg} / \mathrm{ml})$ were tested in SDS-PAGE, and one fraction $(20 \mathrm{mg} / \mathrm{ml})$ was chosen for the conjugation process.

\subsection{IgG Purity by SDS-PAGE}

SDS-PAGE in reducing conditions was performed to assure that no degradation occurred during the storage of purified antibodies. Briefly, one control (dialyzed 
against PBS) and two purified IgG fractions were tested. Samples were mixed with $2 \times$ reducing Laemmli sample buffer (Bio-Rad) and boiled for 5 min. Electrophoresis was done in a $10 \%$ SDS-PAGE gel using Mini-Protean ${ }^{\varpi}$ Tetra Vertical Electrophoresis Cell (Bio-Rad) at $170 \mathrm{~V}$ for 90 minutes. The gel was stained with Coomassie Brilliant Blue G-250 (Bio-Rad).

\subsection{Determining the Concentration of the Antibody}

The measurement of the IgG fraction absorbance was performed by Double Beam Spectrophotometer $6850\left(\right.$ Jenway $^{\oplus}$ ), with a reading range between 250 $400 \mathrm{~nm}$. IgG sample was diluted 20 times with $\mathrm{ddH} 2 \mathrm{O}$ and the absorbance was measured against ddH2O. IgG concentration was calculated using the extinction coefficient of goat IgG.

\subsection{Dialysis of Antibodies Used for Conjugation}

Dialysis of the antibody sample was performed using Micro Float-A-Lyzer ${ }^{\oplus}$ Dialysis Device, (8 - $10 \mathrm{kDa}$ MWCO Spectra/ Por). $150 \mu \mathrm{L}$ of antibody sample was mixed with $50 \mu \mathrm{L}$ of Carbonate buffer $(10 \mathrm{mM}, \mathrm{pH} 9.5)$ and dialyzed against $1 \mathrm{~L}$ of Carbonate buffer ( $10 \mathrm{mM}, \mathrm{pH} 9.5)$ at $+4^{\circ} \mathrm{C}$ with three buffer changes.

\subsection{Determining the Concentration and Amount of Antibody after Dialysis}

Absorbance of dialyzed antibodies was measured to determine the final amount of the IgG to be used for conjugation. IgG sample was diluted 10 times in Carbonate buffer $(10 \mathrm{mM}, \mathrm{pH} 9.5)$ and the absorbance was measured against Carbonate buffer $(10 \mathrm{mM}, \mathrm{pH}=9.5)$. IgG concentration was calculated using the extinction coefficient of goat IgG.

\subsection{SDS-PAGE of Dialyzed IgG}

To confirm that no degradation occurred during dialysis, SDS-PAGE in reducing and non-reducing conditions was done.

\subsection{HRP-IgG Conjugation}

Conjugation was performed using a 1:1 $(\mathrm{w} / \mathrm{w})$ ratio of HRP:IgG by modified periodate-mediated oxidation method. $100 \mu \mathrm{L}$ of freshly prepared $0.1 \mathrm{M}$ Sodium (meta) periodate (Sigma-Aldrich S1878) solution was added to $500 \mu \mathrm{L}$ of Horseradish peroxidase solution $(4 \mathrm{mg} / \mathrm{mL}$ ), type VI-A (Sigma-Aldrich P6782); the color changed from reddish brown to green. The solution was stirred gently on a shaker for 20 minutes at room temperature in dark. To remove the excess of periodate, micro-concentration of the periodate-HRP solution was performed using Omega ${ }^{\text {TM }}$ membrane Nanosep ${ }^{\otimes}$ Centrifugal Devices (MWCO $10 \mathrm{~K}$, Pall) at $8000 \mathrm{rpm}$ for $3 \times 10$ minutes. Sodium acetate buffer $(1 \mathrm{mM}, \mathrm{pH} 4.4)$ was added to a final volume of $250 \mu \mathrm{L}$ and the $\mathrm{pH}$ was adjusted to 9.5 by adding $10 \mu \mathrm{L}$ of Sodium Carbonate buffer $(0.2 \mathrm{M}, \mathrm{pH} 9.5)$. IgG solution $(\sim 2 \mathrm{mg} / 250 \mu \mathrm{L})$ was 
added to the activated HRP solution. The mixture was stirred gently on a shaker for 2 hours at room temperature. $50 \mu \mathrm{L}$ of freshly prepared 0.1 M Sodium Borohydride (Sigma-Aldrich 213462) solution was added to the HRP-IgG mixture. The sample was divided into two fractions: the first fraction $(250 \mu \mathrm{L})$ was incubated with sodium borohydride for 90 minutes at room temperature with gentle shaking, and the second fraction $(250 \mu \mathrm{L})$ was incubated with sodium borohydride overnight at $+4^{\circ} \mathrm{C}$. Both fractions were later dialyzed against $1 \times \mathrm{PBS}(\mathrm{pH}$ 7.2) at $+4^{\circ} \mathrm{C}$. The volume retrieved after dialysis from both methods was $100 \mu \mathrm{L}$ HRP-IgG conjugate.

\subsection{Titration of the Conjugate}

Indirect ELISA was carried out by coating the microplate with $1 \mu \mathrm{g} / 100 \mu \mathrm{L} /$ well of Erythropoietin in Carbonate buffer $(0.1 \mathrm{M}, \mathrm{pH}=9.6)$ and the plate was incubated at $+4^{\circ} \mathrm{C}$ overnight. The next morning, the coating buffer was discarded and $200 \mu \mathrm{L}$ of blocking solution 1\% BSA in PBST (PBS, pH 7.2 with $0.05 \%$ Tween-20) was added, the microplate was covered and kept at room temperature for 2 hours. Then, the blocking buffer was discarded and $100 \mu \mathrm{L}$ of primary rabbit polyclonal anti-Erythropoietin antibodies $(1 \mathrm{mg} / \mathrm{mL}$ diluted 1:10,000 in PBST) were added into wells A to E. $100 \mu \mathrm{L}$ of PBST was added into well $\mathrm{F}$ which was used as a Blank. The microplate was incubated at $37^{\circ} \mathrm{C}$. After 2 hours, manual wash with PBST was performed three times and $100 \mu \mathrm{L}$ of secondary antibodies (either stabilized for 90 minutes or overnight with sodium borohydride) were added to $\mathrm{A}$ to $\mathrm{F}$ wells as follows: 1:200, 1:1000, 1:5000, 1:10,000, 1:20,000, and 1:50,000.

The microplate was incubated at $37^{\circ} \mathrm{C}$ for 1 hour, and then washed manually five times with PBST. $100 \mu \mathrm{L}$ TMB (Sigma T0440) was added and the microplate was kept at room temperature for $20 \mathrm{~min}$. The reaction was stopped by adding $100 \mu \mathrm{L}$ of stopping solution $(1 \mathrm{M} \mathrm{HCl})$, and the Optical Density was read at 450 nm via Spectramax 340PC384 Microplate Reader (Molecular Devices).

\subsection{Western Blot Analysis of Erythropoietin}

Erythropoietin (10 $\mu \mathrm{g} /$ well) was loaded into 14\% SDS-PAGE gel in reducing and non-reducing conditions. Reducing samples were boiled for 5 minutes. The proteins were transferred on a nitrocellulose membrane by semi-dry Western Blot

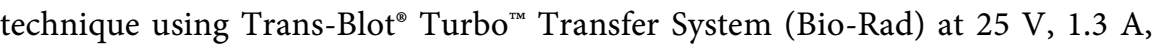
$45 \mathrm{~min}$. The membrane was blocked by $5 \% \mathrm{BSA}$ at $+4^{\circ} \mathrm{C}$ overnight. The blocking solution was discarded and $10 \mathrm{~mL}$ primary rabbit polyclonal anti-Erythropoietin antibodies $(1 \mathrm{mg} / \mathrm{mL}$ diluted 1:10,000 in PBST) solution was added and incubated at room temperature for 2 hours with agitation. The membrane was washed three times with PBST and $10 \mathrm{~mL}$ of secondary antibody solution (1:5000 in PBST of both conjugates either stabilized for 90 minutes and overnight with sodium borohydride) was added and incubated for 1 hour at room temperature with agitation. The membrane was washed three times with PBST 
and stained with TMB (Sigma T0565) for the membranes for 20 minutes.

\subsection{One-Month Stability}

Indirect ELISA and Western Blot analysis were performed to test the stability of Goat anti-rabbit secondary antibodies conjugates at working dilution 1:5000. For Indirect ELISA, two conjugates were used as positive controls: conjugates from June 2017 and October 2017 [10], both prepared using Lightning-Link ${ }^{\circledast}$ HRP antibody labeling kit and diluted 1:5000 in LifeXtend solution (Expedeon).

\section{Results}

SDS-PAGE was done to determine the purity of two eluted fractions of antibodies in reduced conditions. The results showed two bands of each loaded IgG fraction and control sample of molecular weights $\sim 25$ and $50 \mathrm{kDa}$ which correspond to the light and heavy chains of antibodies, respectively (Figure 1).

Measurement of IgG absorbance before dialysis was performed by spectrophotometer at $\lambda=278 \mathrm{~nm}$ and concentration was calculated using the formula: $\mathrm{Cmg} / \mathrm{ml}=\mathrm{Abs} 278 / 1.3 \times$ dilution factor (where 1.3 is the extinction coefficient of goat IgG), the sample was diluted 20 times. Abs278 $=1.381$ (Figure 2). The Concentration of IgG was $21.25 \mathrm{mg} / \mathrm{ml}$.

The concentration of IgG after dialysis was calculated using measured Abs at $278 \mathrm{~nm}, \mathrm{C}=8.37 \mathrm{mg} / \mathrm{ml}$.

SDS-PAGE results of dialyzed IgG showed that no degradation occurred during dialysis (Figure 3 ).

The optimum dilution of HRP-conjugated goat anti-rabbit polyclonal IgG was determined in Indirect ELISA and found to be 1:5000 for both conjugates, whether stabilized for 90 minutes or incubated overnight with Sodium Borohydride. Absorbance readings of Endpoint Assay are shown in Table 1.

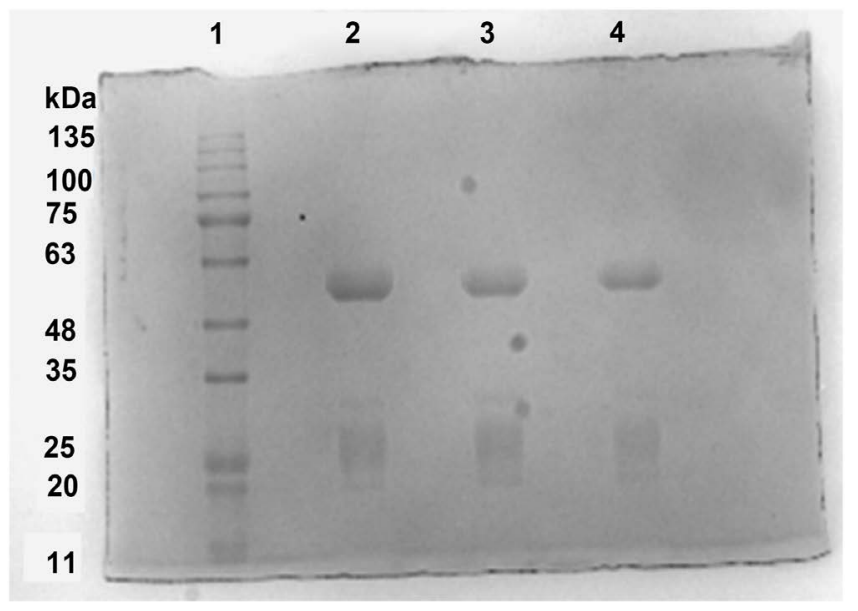

Figure 1. SDS-PAGE Gel of affinity purified goat polyclonal Antibodies. Gel stained with Coomassie Brilliant Blue. Lane 1: Protein Ladder, Lane 2: Control IgG; Lane 3: IgG sample 1; Lane 4: IgG sample 2. 


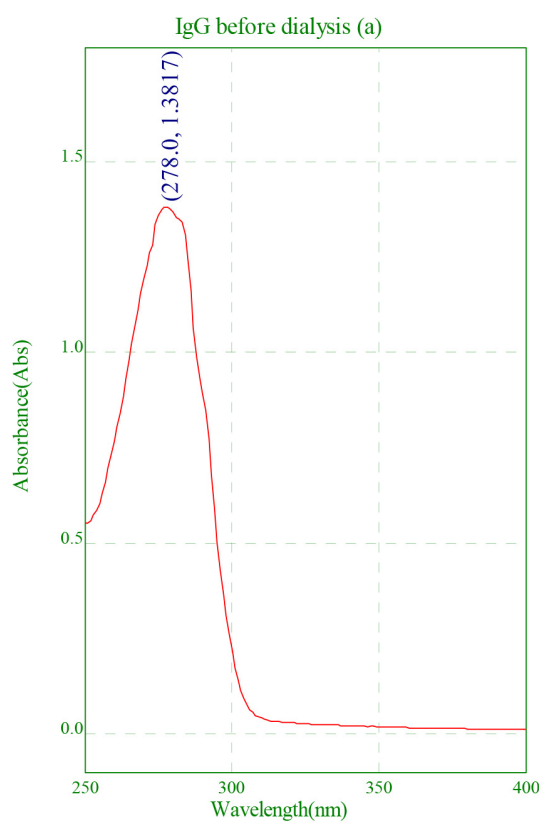

(a)

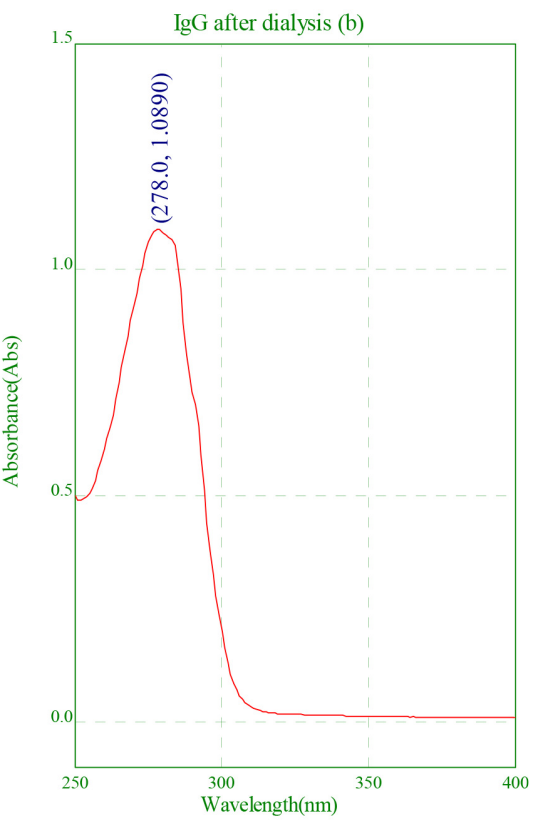

(b)

Figure 2. Absorbance of IgG (a) before dialysis $\lambda=278 \mathrm{~nm}$. Abs278 $=1.381$; (b) after dialysis $\lambda=278 \mathrm{~nm}$. Abs278 $=1.089$.

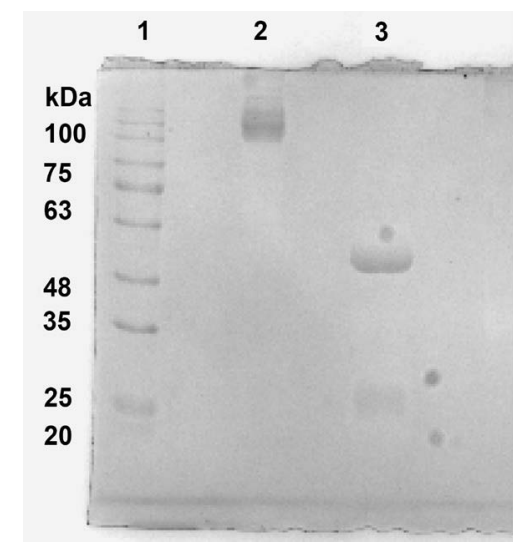

Figure 3. SDS-PAGE Gel of dialyzed goat polyclonal antibodies. Gel stained with Coomassie Brilliant Blue. Lane 1: protein ladder; Lane 2: Dialyzed IgG (non-reducing); Lane 3: Dialyzed IgG (reducing).

Western Blot analysis revealed thick bands of non-reducing and reducing samples of Erythropoietin ( $30.5 \mathrm{kDa})$ incubated with HRP-IgG conjugate stabilized 90 minutes (Figure 4: Lanes 2-5) and HRP-IgG conjugate stabilized overnight (Figure 4: Lanes 6-7).

Also after protein transfer, nitrocellulose membrane stained with Ponceau Red showed bands corresponding to Erythropoietin (Figure 5(a)), whereas no bands were present on SDS-PAGE gel stained with CBB, which confirms that the transfer was successful (Figure 5(b)). 
Table 1. Optical density results for titration of prepared conjugates.

\begin{tabular}{|c|c|c|c|c|c|c|c|}
\hline & A & B & C & $\mathrm{D}$ & $\mathrm{E}$ & F & G \\
\hline Dilution & $1: 200$ & $1: 1000$ & $1: 5000$ & $1: 10,000$ & $1: 20,000$ & $1: 50,000$ & Blank \\
\hline $\begin{array}{c}\text { OD450 Row } 1 \\
\text { (Conjugate Stabilized } \\
90 \mathrm{~min})\end{array}$ & 1.396 & 1.000 & 0.900 & 0.705 & 0.568 & 0.237 & 0.146 \\
\hline $\begin{array}{c}\text { OD450 Row } 2 \\
\text { (Conjugate Stabilized } \\
\text { Overnight) }\end{array}$ & 2.481 & 1.083 & 0.996 & 0.798 & 0.288 & 0.232 & 0.160 \\
\hline
\end{tabular}

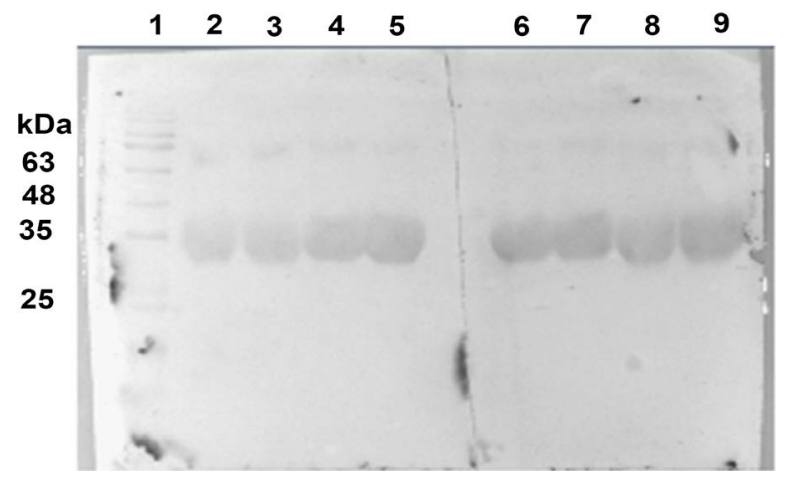

Figure 4. Nitrocellulose membrane after blotting. Lane 1: protein ladder, Lanes 2, 3: non-reduced Erythropoietin (10 $\mu \mathrm{g} /$ well) (conjugate stabilized for 90 mins), Lanes 4, 5: reduced Erythropoietin (10 $\mu \mathrm{g} /$ well) (conjugate stabilized for $90 \mathrm{mins}$ ). Lanes 6, 7: reduced Erythropoietin $(10 \mu \mathrm{g} /$ well) (conjugate stabilized overnight), Lanes 8, 9: non-reduced Erythropoietin (10 $\mu \mathrm{g} /$ well) (conjugate stabilized overnight).

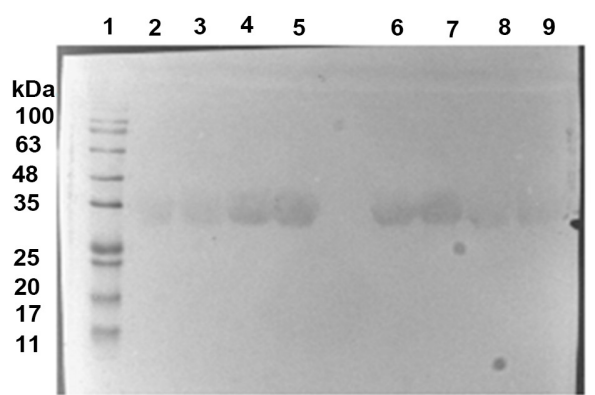

(a)

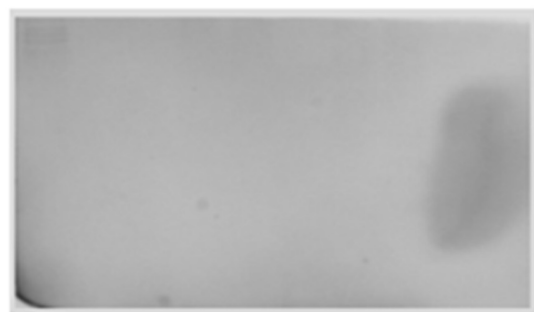

(b)

Figure 5. Nitrocellulose membrane and SDS-PAGE Gel after protein transfer (a) Nitrocellulose membrane stained with Ponceau Red. Lane 1: protein ladder, Lanes 2, 3, 8, 9: Erythropoietin $(10 \mu \mathrm{g} /$ well $)$ under non-reducing conditions, Lanes 4, 5, 6, 7: Erythropoietin $(10 \mu \mathrm{g} /$ well) under reducing conditions. (b) SDS-PAGE Gel stained with CBB.

Indirect ELISA results confirmed that conjugates either stabilized for $90 \mathrm{mi}$ nutes or overnight with Sodium Borohydride are stable after 1 month at $+4^{\circ} \mathrm{C}$. Optical Density was measured using TMB as a substrate and the results of Endpoint Assay were determined on ELISA microplate reader. Absorbance readings are shown in Table 2. 
Table 2. Optical density results of one-month stability of the conjugates.

\begin{tabular}{lcccccc}
\hline $\begin{array}{c}\text { Secondary } \\
\text { Conjugates }\end{array}$ & $\begin{array}{c}\text { In-House } \\
\text { 90min }\end{array}$ & $\begin{array}{c}\text { In-House } \\
\text { 90min }\end{array}$ & Blank & $\begin{array}{c}\text { In-House } \\
\text { Overnight }\end{array}$ & $\begin{array}{c}\text { In-House } \\
\text { Overnight }\end{array}$ & Blank \\
\hline Absorbance & 1.656 & 1.525 & 0.091 & 1.677 & 1.629 & 0.102 \\
Secondary & June 2017 & June 2017 & Blank & $\begin{array}{c}\text { October } \\
2017\end{array}$ & $\begin{array}{c}\text { October } \\
2017\end{array}$ & Blank \\
Conjugates & & & & 1.944 & 2.019 & 0.067 \\
Absorbance & 3.277 & 3.057 & 0.068 & & & \\
\hline
\end{tabular}

For the one-month stability Western Blot analysis revealed bands of non-reducing and reducing samples of Erythropoietin $(30.5 \mathrm{kDa})$, whether membrane was incubated with HRP-IgG conjugate stabilized 90 minutes (Figure 6(a): Lanes 2-5) or HRP-IgG conjugate stabilized overnight (Figure 6(b): Lanes 6-7).

Also, after protein transfer, nitrocellulose membrane stained with Ponceau Red showed bands corresponding to Erythropoietin (Figure 7(a)), whereas no bands were present on SDS-PAGE gel stained with CBB, which confirms that the transfer was successful (Figure 7(b)).

\section{Discussion}

Affinity purified Goat anti-rabbit polyclonal antibodies were used for this research. SDS-PAGE was performed to assure that no degradation occurred during the storage of antibodies. The difference in the number of bands is attributed to sample preparation, which involves breakage of disulfide bonds of the antibody using 2-mercaptoethanol. The fact that no additional bands were observed confirms that there was no degradation of antibodies. These results (Figure 1) comply with the study done by Ezzatifar et al. [11].

Before proceeding with conjugation, the antibodies were dialyzed against Carbonate buffer ( $10 \mathrm{mM}, \mathrm{pH} 9.5)$ at $+4^{\circ} \mathrm{C}$ overnight, as was done by Tijssen et al. in their experiment [6], in contrast to other studies which used fractionation of sera with sodium sulfate, followed by passage through a diethylaminoethyl cellulose column by Yoshitake et al. [12].

Tijssen et al. and Boorsma et al. performed purification of HRP by chromatofocusing then ion exchange chromatography [6] and by gel filtration on Sephadex G-25 and Ultrogel AcA-44 [13], respectively, before proceeding with the oxidation step. Whereas, in this research no purification was required because Peroxidase (Sigma-Aldrich) Type VI-A, isolated from horseradish roots (Amoraciarusticana) essentially salt free, was used.

SDS-PAGE results of dialyzed IgG in reducing and non-reducing conditions (Figure 3), verified that antibodies were not degraded. In non-reducing conditions only one band of high molecular weight (MW) appeared which refers to the IgG molecule and in reducing conditions two bands of MW $50 \mathrm{kDa}$ and 25 $\mathrm{kDa}$ appeared, which correspond to heavy and light chains of antibodies, respectively. 


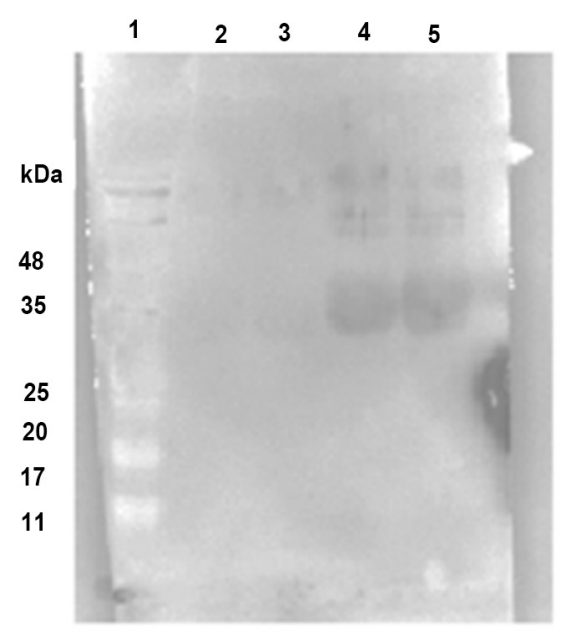

(a)

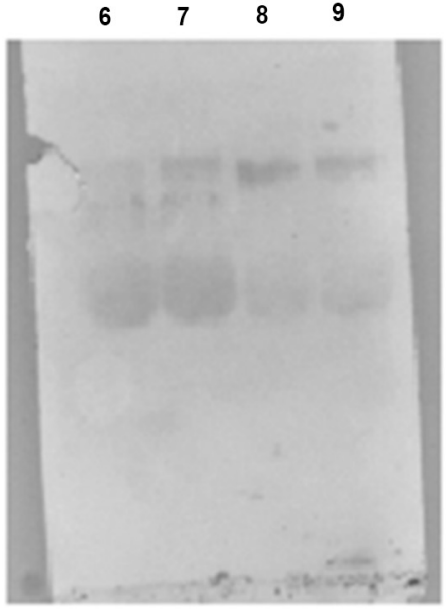

(b)

Figure 6. Nitrocellulose membrane of Erythropoietin after blotting. (a) Lane 1: Protein ladder, Lanes 2, 3: non-reduced Erythropoietin (10 $\mu \mathrm{g} /$ well) (conjugate stabilized for 90 mins), Lanes 4, 5: reduced Erythropoietin (10 $\mathrm{g}$ /well) (conjugate stabilized for $90 \mathrm{mins}$ ). (b) Lanes 1, 2: reduced Erythropoietin (10 $\mu \mathrm{g} /$ well) (conjugate stabilized overnight), Lanes 3, 4: non-reduced Erythropoietin (10 $\mu \mathrm{g} /$ well) (conjugate stabilized overnight).

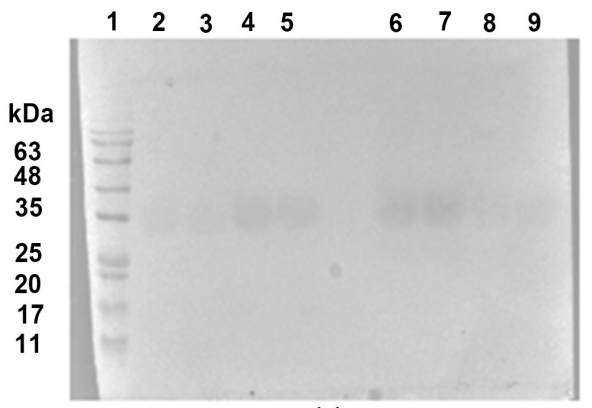

(a)

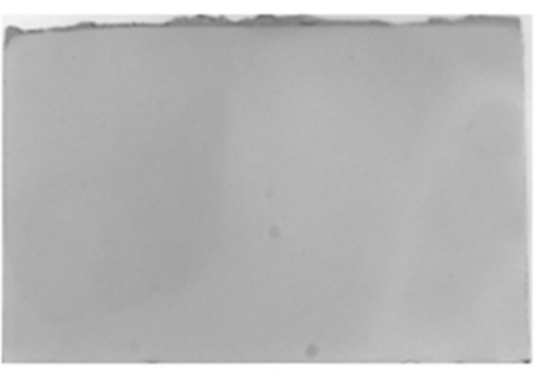

(b)

Figure 7. Nitrocellulose membrane and SDS-PAGE Gel after protein transfer (a) Nitrocellulose membrane stained with Ponceau Red. Lane 1: Protein ladder, Lanes 2, 3, 8, 9 : Erythropoietin $(10 \mu \mathrm{g} /$ well $)$ in non-reducing conditions, Lanes 4, 5, 6, 7: Erythropoietin $(10 \mu \mathrm{g} /$ well) in reducing conditions. (b)SDS-PAGE Gel stained with CBB.

Nakane and Kawaoi used FDNB to prevent self-coupling of activated HRP [7]. In this study this step was skipped, since HRP has few lysine molecules, which is helpful in limiting unwanted self-coupling [11]. Also, the periodate solution provides a slightly acidic medium which prevents the self-coupling of HRP [14].

According to the protocol of Eivazi et al., Sodium Periodate was added to the solution of HRP and kept at room temperature for 20 minutes in a dark place. To remove the excess of periodate after activation of HRP, micro-concentration was done instead of dialysis against Acetate buffer performed by Beyvazi et al., Eivazi et al. and Ezzatifar et al., or through Sephadex G-25 performed by Tijssen et al. [6] [14] [15].

Solution of antibodies dialyzed against Carbonate buffer was added to the ac- 
tivated HRP solution and the mixture was kept at room temperature for 2 hours. Sodium Borohydride was added to the HRP-IgG solution and incubated either for 90 minutes, or overnight, unlike Ramesh Kumar $\mathrm{K}$ et al. who stabilized conjugate for $10 \mathrm{~min}$ at room temperature [16]. Finally, the conjugates were dialyzed against PBS at $+4^{\circ} \mathrm{C}$ overnight as per protocol of Nakane and Kawaoi [7].

The titer of conjugates was determined by Indirect ELISA. The results showed that the optimum dilution of HRP-IgG conjugates prepared either by stabilization for 90 minutes or overnight with Sodium Borohydride was 1:5000 with an Optical Density of 0.9 and 0.996, respectively. Although the dilutions of the conjugates resembled the preparations by Eivazi et al. [15], however, optimum titer obtained was different.

Indirect ELISA was also performed to test the one-month stability of the conjugates. HRP-IgG conjugates, stabilized for 90 minutes or overnight with Sodium Borohydride and stored at $+4^{\circ} \mathrm{C}$ showed Optical Density readings of 1.656, 1.525 and $\mathrm{OD}_{450} 1.677,1.629$, respectively. Those readings were compared to the readings of the blank with $\mathrm{OD}_{450} 0.091,0.102$ (where no primary antibodies were added) and the two positive controls with $\mathrm{OD}_{450} 3.277,3.057$ (June 2017 conjugates) and $\mathrm{OD}_{450}$ 1.944, 2.019 (October 2017 conjugate). All the above results confirm that both conjugates were stable.

Western Blot results of Erythropoietin, under reducing and non-reducing conditions, using conjugated secondary antibodies either stabilized for $90 \mathrm{mi}-$ nutes or overnight with Sodium Borohydride, showed that both conjugates were effective, since clear bands of Erythropoietin were visualized on the nitrocellulose membrane (Figure 4).

Western Blot of Erythropoietin, under reducing and non-reducing conditions, was also performed to test the stability of the conjugates after 1 month, using conjugated secondary antibodies stabilized for 90 minutes or overnight with Sodium Borohydride and stored at $+4^{\circ} \mathrm{C}$. The results showed that both conjugates were still effective since clear bands of Erythropoietin were visualized on the nitrocellulose membrane (Figure 6).

\section{Conclusions}

Antibodies can be labeled with a variety of molecules. Enzymes are the most useful tags to label antibodies since obtained conjugates can be used to detect and quantify protein of interest using analytical techniques such as ELISA and Western Blot. Therefore, enzyme-labeled antibodies can be used in the pharmaceutical industry for the quality control of therapeutic proteins.

In-house conjugate of horseradish peroxidase with goat polyclonal antibodies was produced by a modified process of the previously described periodate oxidation method. Conjugate titration was performed in Indirect ELISA, where the optimum dilution for HRP-IgG conjugate was determined as 1:5000. Functionality of prepared conjugates was also tested by semi-dry Western Blot technique of the Erythropoietin, using TMB as substrate. The prepared conjugates 
were stored at $+4^{\circ} \mathrm{C}$ and were re-tested after one month in Indirect ELISA and Western Blot techniques. All results were satisfying.

\section{Funding}

This research received no external funding.

\section{Conflicts of Interest}

The authors declare no conflict of interest.

\section{References}

[1] Making Antibody Labeling Easier. Guide to Antibody Labeling and Detection Methods. INNOVA.

https://www.biomol.de/dateien/protocols/Innova/Innova--Antibody-Labeling-Guid e.pdf

[2] Antibody Labeling: Types of Labels. Advansta. https://advansta.com/wikis/antibody-labeling-types-labels

[3] Gupta, S., Batra, S. and Jain, M. (2014) Antibody Labeling with Radioiodine and Radiometals. Methods in Molecular Biology, 1141, 147-157. https://doi.org/10.1007/978-1-4939-0363-4_9

[4] Behrens, C. and Liu, B. (2014) Methods for Site-Specific Drug Conjugation to Antibodies. $M A b s, 6,46-53$. https://doi.org/10.4161/mabs.26632

[5] Nigel, C.V. (2004) Horseradish Peroxidase: A Modern View of a Classic Enzyme. Phytochemistry, 65, 249-259. https://doi.org/10.1016/j.phytochem.2003.10.022

[6] Tijssen, P. and Kurstak, E. (1984) Highly Efficient and Simple Methods for the Preparation of Peroxidase and Active Peroxidase-Antibody Conjugates for Enzyme Immunoassay. Analytical Biochemistry, 136, 451-457. https://doi.org/10.1016/0003-2697(84)90243-4

[7] Nakane, P. and Kawaoi, A. (1974) Peroxidase-Labeled Antibody: A New Method of Conjugation. Journal of Histochemistry and Cytochemistry, 22, 1084-1091. https://doi.org/10.1177/22.12.1084

[8] Avrameas, S., Ternynck, T. and Guesdon, J. (1978) Coupling of Enzymes to Antibodies and Antigens. Scandinavian Journal of Immunology, 8, 7-23. https://doi.org/10.1111/j.1365-3083.1978.tb03880.x

[9] Ausubel, F.M., Brent, R., Kingston, R.E., Moore, D.D., Seidman, J.G., Smith, J.A. and Struhl, K. (2003) Immunology. In: Current Protocols in Molecular Biology, Wiley, Hoboken, 1647.

[10] Bassil, M., Pavliuchenko, N. and Raya, E. (2018) Syringe Purification and HRP-Conjugation of Goat IgGs Used in Quality Control of Erythropoietin. Journal of Applied Biotechnology, 6, 11-18. https://doi.org/10.5296/jab.v6i2.12829

[11] Ezzatifar, F., Majidi, J., Baradaran, B., Maleki, L.A., Abdolalizadeh, J. and Yousefi, M. (2015) Large-Scale Generation and Characterization of Anti-Human IgA Monoclonal Antibody in Ascitic Fluid of Balb/c. Advanced Pharmaceutical Bulletin, 5, 97-102.

[12] Yoshitake, S., Imagawa, M., Ishikawa, E., Niitsu, Y., Urushizaki, I., Nishiura, M., Kanazawa, R., Kurosaki, H., Tachibana, S., Nakazawa, N. and Ogawa, H. (1982) Mild and Efficient Conjugation of Rabbit Fab' and Horseradish Peroxidase Using Maleimide Compound and Its Use for Enzyme Immunoassay. Journal of Biochemi- 
stry, 92, 1413-1424. https://doi.org/10.1093/oxfordjournals.jbchem.a134065

[13] Boorsma, D.M. and Streefkerk, J.G. (1979) Periodate or Glutaraldehyde for Preparing Peroxidase Conjugates? Journal of Immunological Methods, 30, 245-255.

[14] Beyvazi, K., Hampton, S., Kwasowski, P., Fickling, S., Marks, V. and Clift, R. (1987) Comparison of Horseradish Peroxidase and Alkaline Phosphatase-Labelled Antibodies in Enzyme Immunoassays. Annals of Clinical Biochemistry, 24, 145-152. https://doi.org/10.1177/000456328702400204

[15] Eivazi, S., Majidi, J., Maleki, L., Abdolaizadeh, J., Yousfi, M., Ahmadi, M., Dadashi, S., Moradi, Z. and Zolali, E. (2015) Production and Purification of a Polyclonal Antibody against Purified Mouse IgG2b in Rabbits towards Designing Mouse Monoclonal Isotyping Kits. Advanced Pharmaceutical Bulletin, 5, 109-113.

[16] Ramesh Kumar, K., Xiavour, S., Latha, S., Kumar, V. and Sukumaran (2014) Anti-Human IgG-Horseradish Peroxidase Conjugate Preparation and Its Use in ELISA and Western Blotting Experiments. Journal of Chromatography and Separation Techniques, 5, 211. https://doi.org/10.4172/2157-7064.1000211 